\title{
HUBUNGAN DUKUNGAN KELUARGA DENGAN KEPATUHAN LANSIA DALAM MENGIKUTI POSYANDU LANSIA DI POSYANDU LANSIA "SAKURA" SAMARINDA TAHUN 2017
}

\author{
Nina Rahmadiliyani ${ }^{1}$
}

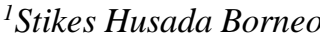

\begin{abstract}
Abstrak
Dukungan keluarga merupakan salah satu bentuk dari terapi keluarga, melalui keluarga berbagai masalah kesehatan bisa muncul sekaligus dapat diatasi. Posyandu lansia merupakan pos pelayanan terpadu untuk masyarakat usia lanjut yang kegiatannya meliputi kegiatan preventif, promotif, kuratif, dan rehabilitatif.

Metode penelitian yang digunakan dalam penelitian ini adalah metode deskritif analitik dengan rancangan Cross Sectional. Penelitian ini dilakukan mulai tanggal 24 September sampai 30 September 2017. Sampel pada penelitian ini adalah lansia yang datang di Posyandu Lansia tahun 2017 yang memenuhi syarat inklusi dan ekslusi dengan teknik purposive sampling. Jumlah sampel yang didapatkan adalah 51 responden. Pengambilan data dilakukan dengan menggunakan kuisioner. Data yang telah terkumpul kemudian dianalisis menggunakan uji statistik Chi Square $\left(\mathrm{X}^{2}\right)$.

Hasil penelitian yang didapat adalah dukungan keluarga rendah menyebabkan kepatuhan lansia juga rendah. Hasil uji statistik menunjukkan bahwa nilai Chi-Square yaitu 7,849 lebih besar dibandingkan dengan nilai tabel 3,841 ( $\left.\mathrm{X}_{\text {hitung }} 7,849>\mathrm{X}_{\text {tabel }} 3,841\right)$ dan $\mathrm{P}_{\text {Value }}=0,003$, dimana Sig $<$ nilai $\alpha(0,003<0,05)$.

Kesimpulan yang didapat yaitu ada hubungan yang signifikan antara dukungan keluarga dengan kepatuhan lansia mengikuti posyandu lansia di Posyandu Lansia "Sakura" Samarinda tahun 2017. Berdasarkan hasil penelitian sebagian besar lansia mendapatkan dukungan keluarga yang rendah sehingga kepatuhan lansia pun rendah.
\end{abstract}

Kata Kunci : Dukungan Keluarga, Kepatuhan, Lansia, Kesehatan

\begin{abstract}
Correlation between family support and pursuance of oldster in participating in oldster nursing home Sakura Samarinda 2017. Family support is very fundamental need for every person. Many problems can be resolved through share and talk to the relatives. Oldster nursing home is an integrated nursing home for the elder which is an expert of preventing, promotive, curative, and rehabilitative program.

The method used in this research is analitical descriptive method by applying cross sectional. This research was conducted on 24 Septmber until 30 September 2017. The samples of this research are those who are oldsters registered in Elder Nursing home Sakura 2017 who are eligible for inclusive or exclusive with purpose sampling. the total amount of samples acquired are 51 respondents. Data collected through questionnaires, and analyzed using chi square statistical test $\left(X^{2}\right)$.

The result of this research is that lack of family support affecting low pursuance of the elders. Statistical test suggested that chi-square value 7,849 bigger than the table value 3,481 ( $\left.X_{\text {count }} 7.849>X_{\text {table }} 3.481\right)$ and $P_{\text {value }}=$ 0,003 whereas Sig $<\alpha$ value $(0,003<0,05)$.

In conclusion, there is a significant correlation between family support and pursuance of oldster in participating in oldster nursing care Sakura Samarinda 2017. According to the result of this research, lack of family support causing lack of pursuance of the oldster.
\end{abstract}

Keywords: family support, pursuance, elder, health

\section{PENDAHULUAN}

Keluarga merupakan support system utama bagi lansia dalam mempertahankan kesehatannya. Peranan keluarga dalam perawatan lansia yaitu menjaga atau merawat lansia, mempertahankan dan meningkatkan status mental, mengantsipasi perubahan sosial ekonomi serta memberikan motivasi dan memfasilitasi kebutuhan spritual bagi lansia (Maryam dkk, 2008). Keluarga juga mempunyai peran sebagai motivator, educator, fasilitator. Upaya yang dapat dilakukan keluarga untuk melaksanakan perannya sebagai motivator 
yaitu memberikan dukungan kepada lansia untuk dapat menjalani sisa hidupnya dengan baik, hal ini juga berfungsi sebagai strategi preventif pada anggota keluarga yang sakit, peran educator keluarga dapat memberikan informasi kesehatan pada lansia, hal ini dapat berfungsi sebagai usaha promotif dari keluarga. Peran sebagai fasilitator keluarga mampu membimbing dapat berfungsi sebagai rehabilitative maupun kuratif (Hidayat \& Aisyah, 2010).

Dukungan keluarga dapat memberikan kekuatan satu sama lain dan kemampuan anggota keluarga menciptakan suasana saling memiliki, untuk memenuhi kebutuhan perkembangan keluarga. Menurut Friedman (1998) disebutkan ada empat jenis dukungan keluarga yaitu: dukungan informasi, dukungan penilaian, dukungan instrumental dan dukungan emosional. Ini merupakan strategi preventif yang paling baik, yang bertujuan untuk meningkatkan dukungan keluarga yang adekuat dalam membantu anggota keluarga yang mempertahankan kesehatan. Keluarga yang baik akan berpengaruh positif, sedangkan keluarga yang kurang baik akan berpengaruh negatif bagi perkembangan lansia (Handayani \& Wahyuni, 2012).

Hasil penelitian (Hasugian, Lubis, \& Tukiman, 2012) menjelaskan bahwa tingkat kehadiran lanjut usia di posyandu lanjut usia dipengaruhi oleh pengetahuan dan dukungan memanfaatkan posyandu lansia memiliki pengetahuan yang kurang, banyak diantaranya kurang memanfaatkannya.

Kendala yang dialami lansia dalam menghadiri posyandu lansia selain dukungan dari keluarga yaitu lansia yang memliki peran tambahan dalam keluarga untuk menjaga cucu, lansia yang ikut serta dalam mencukupi kebutuhan hidup keluarga dan aksesibilitas posyandu lansia yang jauh dari tempat tinggal lansia (Sumiati, Suriati, Iwan, \& Ramdan, 2012).

Hasil penelitian ( Hidayat, \& Aisyah, 2010), menjelaskan bahwa peran keluarga sangat mempengaruhi terhadap status kesehatan lansia, disimpulkan bahwa jika peran keluarga baik maka diharapkan status kesehatan lansia juga baik dan sebaliknya jika peran keluarga kurang, maka status kesehatan pada lansia juga buruk.

\section{METODE PENELITIAN}

Jenis penelitian yang digunakan adalah analitik korelasional dengan pendekatan cross sectional, survey cross sectional ialah suatu penelitian untuk mempelajari dinamika kolerasi antara faktor-faktor risiko dengan efek, dengan cara pendekatan, observasi atau pengumpulan data sekaligus pada suatu saat (point time approach). Artinya, tiap subjek penelitian hanya diobservasi sekali saja dan pengukuran dilakukan terhadap status karakter atau variable subjek pada saat pemeriksaan. Hal ini tidak berarti bahwa semua subjek penelitian diamati pada waktu yang sama (Notoatmodjo, 2002).

\section{HASIL PENELITIAN}

dari hasil pengambilan data didapatkan sampel 42 responden diperoleh hasil data sebagai berikut:

1. Analisis univariat

a. Variabel independen

Variabel bebas dalam penelitian ini adalah dukungan keluarga. Dukungan keluarga dibagi dalam 2 kategori yaitu tinggi dan rendah. Berdasarkan kuesioner yang disebarkan pada seluruh responden yang berjumlah 51 orang yaitu lansia yang datang ke Posyandu Lansia Sakura 
Samarinda tahun 2017, maka didapatkan hasil sebagai berikut:

Tabel 1. Distribusi Frekuensi Dukungan Keluarga di Wilayah Kerja Posyandu Lansia Sakura Samarinda Tahun 2017

\begin{tabular}{ccc}
\hline $\begin{array}{c}\text { Dukungan } \\
\text { Keluarga }\end{array}$ & Frekuensi Persentase \\
\hline Rendah & 29 & 56.9 \\
Tinggi & 22 & 43.1 \\
\hline Total & $\mathbf{5 1}$ & $\mathbf{1 0 0 . 0}$ \\
\hline
\end{tabular}

Pada tabel diatas menunjukkan bahwa dari 51 responden yang mendapat dukungan keluarga rendah sebanyak 29 orang $(56,9 \%)$ dan yang mendapat dukungan keluarga tinggi sebanyak 22 orang $(43,1 \%)$. Berdasarkan data tersebut dapat disimpulkan bahwa sebagian besar lansia mendapatkan dukungan yang rendah untuk mengikuti posyandu lansia.

b. Variabel dependen

Variabel terikat dalam penelitian ini adalah kepatuhan lansia mengikuti posyandu lansia. Berdasarkan kuisioner diperoleh distribusi frekuensi responden berdasarkan kepatuhan lansia dalam mengikuti posyandu lansia di Posyandu Sakura Samarinda tahun 2017, maka didapatkan hasil sebagai berikut:
Tabel 2. Distribusi Frekuensi Kepatuhan Lansia di Wilayah Kerja Posyandu Lansia Sakura Samarinda Tahun 2017

\begin{tabular}{ccc}
\hline $\begin{array}{c}\text { Kepatuhan } \\
\text { Lansia }\end{array}$ & Frekuensi Persentase \\
\hline Tidak Patuh & 33 & 64.7 \\
Patuh & 18 & 35.3 \\
\hline Total & $\mathbf{5 1}$ & $\mathbf{1 0 0 . 0}$ \\
\hline
\end{tabular}

Pada tabel diatas menunjukkan bahwa dari 51 responden yang tidak patuh mengikuti posyandu lansia sebanyak 33 orang $(64,7 \%)$ dan yang patuh mengikuti posyandu lansia sebanyak 18 orang $(35,3 \%)$. Berdasarkan data tersebut dapat disimpulkan bahwa lansia yang tidak patuh mengikuti posyandu lebih tinggi dibanding yang patuh mengikuti posyandu lansia.

2. Analisis bivariat

Analisa bivariat dilakukan terhadap dua variabel yang diduga berhubungan atau berkorelasi. Variabel bebas memiliki pengaruh terhadap variabel terikat. Sehingga analisis ini dilakukan untuk melihat hubungan dukungan keluarga dengan kepatuhan lansia dalam mengikuti posyandu lansia di Posyandu Lansia Sakura Samarinda tahun 2017.

Tabel 3. Hubungan Dukungan Keluarga dengan Kepatuhan Lansia dalam Mengikuti Posyandu Lansia di Posyandu Lansia Sakura Samarinda Tahun 2017

\begin{tabular}{|c|c|c|c|c|c|c|c|c|c|}
\hline \multirow{3}{*}{$\begin{array}{c}\text { Dukungan } \\
\text { Keluarga }\end{array}$} & \multicolumn{4}{|c|}{ Kepatuhan Lansia } & \multicolumn{2}{|c|}{ Total } & \multirow[t]{3}{*}{$\mathbf{P}_{\text {Value }}$} & \multirow{3}{*}{$\begin{array}{c}\mathbf{X}^{2} \\
\text { Hitung }\end{array}$} & \multirow[t]{3}{*}{ OR } \\
\hline & \multicolumn{2}{|c|}{ Tidak Patuh } & \multicolumn{2}{|c|}{ Patuh } & \multirow[b]{2}{*}{$\mathrm{N}$} & \multirow[b]{2}{*}{$\%$} & & & \\
\hline & $\mathrm{N}$ & $\%$ & $\mathrm{~N}$ & $\%$ & & & & & \\
\hline Rendah & 24 & $47,1 \%$ & 5 & $9,8 \%$ & 29 & $56,9 \%$ & \multirow{3}{*}{0,003} & \multirow{3}{*}{7,849} & \multirow{3}{*}{6,933} \\
\hline Tinggi & 9 & $17,6 \%$ & 13 & $25,5 \%$ & 22 & $43,1 \%$ & & & \\
\hline Total & 33 & $64,7 \%$ & 18 & $35,3 \%$ & 51 & $100,0 \%$ & & & \\
\hline
\end{tabular}


Tabel diatas menjelaskan bahwa dari 29 orang $(56,9 \%)$ yang memiliki dukungan keluarga rendah sebanyak 24 orang $(47,1 \%)$ tidak patuh mengikuti posyandu lansia dan 5 orang $(9,8 \%)$ patuh mengikuti posyandu lansia. Sedangkan dari 22 orang $(43,1 \%)$ yang memiliki dukungan keluarga tinggi sebanyak 9 orang $(17,6 \%)$ tidak patuh mengikuti posyandu lansia dan 13 orang $(25,5 \%)$ patuh mengikuti posyandu lansia.

Dari tabel 4.10 mengenai tabel silang antara dukungan keluarga dengan kepatuhan lansia dalam mengikuti posyandu lansia di Posyandu Lansia Sakura Samarinda tahun 2017 melalui uji statistik menunjukkan bahwa nilai Chi-Square yaitu 7,849 lebih besar dibandingkan dengan nilai tabel 2,706 ( $\mathrm{X}_{\text {hitung }} 7,849>\mathrm{X}_{\text {tabel }}$ 2,706). Hasil uji statistik didapatkan $\mathrm{P}$ value $=0,003$, dimana $\operatorname{Sig}<$ nilai $\alpha$ $(0,003<0,1)$ sehingga dapat disimpulkan bahwa ada hubungan yang signifikan antara dukungan keluarga dengan kepatuhan lansia mengikuti posyandu lansia atau Ha diterima. Dari hasil analisa didapatkan nilai Odd Ratio (OR) yang artinya lansia yang mendapat dukungan keluarga tinggi mempunyai peluang sebanyak 6,933 kali untuk patuh dalam mengikuti posyandu lansia dibandingkan dengan lansia yang mendapat dukungan keluarga rendah.

\section{PEMBAHASAN}

Hasil uji statistik yang didapatkan dari uji chi-square tentang hubungan dukungan keluarga dengan kepatuhan lansia dalam mengikuti posyandu lansia menunjukkan bahwa nilai ChiSquare yaitu 7,849 lebih besar dibandingkan dengan nilai tabel 2,706 $\left(\mathrm{X}^{2}\right.$ hitung 7,849 $>\mathrm{X}_{\text {tabel }}^{2}$ 2,706). Hasil uji statistik didapatkan $\mathrm{P}_{\text {Value }}=0,003$, dimana Sig $<$ nilai $\alpha(0,003<0,1)$ sehingga dapat disimpulkan bahwa ada hubungan yang signifikan antara dukungan keluarga dengan kepatuhan lansia mengikuti posyandu lansia atau Ha diterima.

Berdasarkan hasil Risk Estimate didapatkan nilai Odd Ratio (OR) yang artinya lansia yang mendapat dukungan keluarga tinggi mempunyai peluang sebanyak 6,933 kali untuk patuh dalam mengikuti posyandu lansia dibandingkan dengan lansia yang mendapat dukungan rendah yang mana dari 51 responden terdapat 29 orang $(56,9 \%)$ yang mendapat dukungan keluarga rendah dan 22 orang $(43,1 \%)$ yang mendapat dukungan keluarga tinggi.

Hasil penelitian menunjukkan bahwa dari 51 orang $(100 \%)$ responden hanya 18 orang $(35,3 \%)$ lansia yang patuh menghadiri posyandu lansia dengan dukungan keluarga baik dukungan keluarga tinggi maupun dukungan keluarga rendah. Jadi sebagian besar lansia tidak patuh dalam menghadiri posyandu lansia. Ini dimungkinkan karena sebagian besar lansia tidak di ingatkan oleh keluarga kapan jadwal posyandu lansia dan kesibukan dari para lansia.

Hal ini sependapat dengan penelitian yang dilakukan oleh Nasution (2011) menunjukkan bahwa pengetahuan, sikap, dukungan keluarga, dukungan kader, dan jarak berpengaruh secara signifikan terhadap pemanfaatan posyandu lansia. Artinya bahwa lansia yang memanfaatkan pelayanan posyandu yaitu lansia yang memiliki pengetahuan dan sikap yang baik tentang posyandu lansia, dukungan keluarga dan dukungan kader yang baik untuk mengikuti kegiatan posyandu lansia, dan memiliki akses yang terjangkau ke posyandu lansia. Sementara variabel dukungan kepala desa tidak berpengaruh secara signifikan terhadap pemanfaatan posyandu lansia. Untuk meningkatkan pemanfaatan posyandu lansia, maka disarankan bagi Dinas Kesehatan agar memberikan insentif bagi kader yang aktif dalam melakukan kegiatan posyandu lansia supaya tetap menjaga 
kesinambungan kegiatan posyandu lansia. Selain itu, keluarga diharapkan lebih meningkatkan kepedulian atau perhatian yang diberikan kepada lansia dengan ikut serta menemani lansia ke posyandu lansia.

$$
\text { Hasil penelitian Nurhaida }
$$
menunjukkan bahwa ada pengaruh peran keluarga dan peran kader terhadap pemanfaatan pelayanan posyandu lansia. Peran keluarga (Peran berdasarkan harapan maysarakat) P-Value 0.003, Peran kader (membangkitkan kemauan untuk berubah) P-Value 0.000. Peran keluarga dan kader terhadap pemanfaatan posyandu lansia memiliki peranan yang sangat penting terhadap kesehatan lansia. Disarankan keluarga melaksanakan perannya terhadap lansia, melakukan perawatan terhadap lansia, Hendaknya kader mengajak para lansia untuk datang ke posyandu, menjelaskan kepada lansia tentang manfaat posyandu, menyarankan kepada lansia untuk menjaga kesehatannya dan mengikuti penyuluhan gizi dan PHBS pada lansia.

$$
\text { Hasil penelitian Khotimah }
$$
menunjukkan mayoritas responden berumur 55-64 tahun, berjenis kelamin perempuan, tinggal bersama suami/istri dan anak, berstatus kawin, pendidikan tamat SD, pekerjaan petani, jarak ke posyandu dekat sedangkan pendapatan, pengetahuan, sikap, dukungan sosial dan peran kader termasuk kategori kurang. Variabel yang berhubungan secara signifikan dengan pemanfaatan posyandu lansia yaitu pengetahuan $(\mathrm{p}=0,000)$, sikap $(\mathrm{p}=0,001)$, dukungan sosial $(\mathrm{p}=0,010)$ dan peran kader $(\mathrm{p}=0,009)$. Sedangkan variabel yang tidak berhubungan dengan pemanfaatan posyandu lansia yaitu umur, jenis kelamin, status tinggal, status perkawinan, pendidikan, pekerjaan dan pendapatan.

\section{KESIMPULAN}

Berdasarkan penelitian yang dilakukan di Posyandu Lansia Sakura tahun 2017 didapatkan hasil sebagai berikut:

1. Dukungan keluarga diperoleh hasil dari 51 responden yang mendapat dukungan keluarga rendah sebanyak 29 orang $(56,9 \%)$ dan yang mendapat dukungan keluarga tinggi sebanyak 22 orang $(43,1 \%)$.

2. Kepatuhan lansia mengikuti posyandu lansia diperoleh hasil dari 51 responden yang tidak patuh mengikuti posyandu lansia sebanyak 33 orang $(64,7 \%)$ dan yang patuh mengikuti posyandu lansia sebanyak 18 orang $(35,3 \%)$.

3. Berdasarkan hasil penelitian uji ChiSquare diperoleh $\mathrm{X}^{2}$ hitung 7,849> $\mathrm{X}_{\text {tabel }}$ 2,706 dan nilai $\mathrm{P}_{\text {Value }}=0,003$, dimana Sig $<$ nilai $\alpha(0,003<0,1)$, terdapat hubungan yang signifikan antara dukungan keluarga dengan kepatuhan lansia mengikuti posyandu lansia atau Ha diterima.

\section{DAFTAR PUSTAKA}

Arikunto, S. 2006. Metodologi Penelitian Kesehatan. Jakarta: Rineka cipta

Ariwibowo, Rinto. 2012. Proposal Penelitian Hubungan Pengetahuan Dengan Status Kunjungan Posyandu Lansia. http://nursemenden.blogspot.com. Diakses tanggal 19 Maret 2015

2006. Prosedur Penelitian Suatu

Pendekatan Praktik (Edisi Revisi V). Jakarta: Rineka Cipta

.2010. Prosedur Penelitian Suatu

Pendekatan Praktik (Edisi Revisi VII). Jakarta: Rineka Cipta 
BPS, (2009). Human Development Index (HDI) by

Province

and

National,

http://dds.bps.go.id/eng/tab_sub/view.php?tabel=1

\&daftar=1\&id_subyek=26\&notab=2 diakses 3 maret 2017

Crandal, $R$. (1973). The measurement of selfesteem and related construk, Pp. 80-82 in J.P. Robinson \& P.R. Shaver (Eds), Measures of social psychological attitudes. Revised edition. Ann Arbor: ISR

Erfandi. 2008. Pengelolaan Posyandu Lansia. http:// puskesmas-oke.blogspot.com. diakses 3 maret 2017

Henniwati. 2008. Faktor-Faktor yang Mempengaruhi Pemanfaatan Pelayanan Posyandu Lanjut Usia di Wilayah Kerja Puskesmas Kabupaten Aceh Timur [tesis]. Medan: Universitas Sumatera Utara.

Hermawanto, Heri. 2010. Menyiapkan Karya Tulis Ilmiah. Jakarta: Trans Info Media.

Khotimah, Siti Khusnul (2011) Faktor-Faktor Yang Berhubungan Dengan Pemanfaatan Posyandu Lansia Di Wilayah Kerja Puskesmas Walikukun Kabupaten Ngawi. Undergraduate thesis, Diponegoro University.

Nasution, Zulkarnain. 2011. Pengaruh Pengetahuan, Sikap, Dukungan Keluarga dan Kader terhadap Pemanfaatan Posyandu Lanjut Usia di Wilayah Kerja Puskesmas Bandar Dolok Kecamatan Pagar Merbau Kabupaten Deli Serdang. Medan: Universitas Sumatera Utara. Nurhaida. 2012. Pengaruh Peran Keluarga dan Kader Lansia terhadap Pemanfaatan Pelayanan Posyandu Lansia di Wilayah Kerja Puskesmas Bandar Khalipah Kecamatan Percut Sei Tua. Medan: Universitas Sumatera Utara.
Nursalam. (2011). Konsep dan Penerapan Metodologi Penelitian Ilmu Keperawatan. Jakarta: Salemba Medika.

Notoatmodjo, S. (2007). Promosi Kesehatan \& Ilmu Perilaku Rineka Cipta, Jakarta.

Notoatmodjo, S. 2010. Metodologi Penelitian Kesehatan., Jakarta: Rineka Cipta.

UU RI Nomor 13 tahun 1998 tentang Kesejahteraan Lanjut Usia

UU RI Nomor 23 tahun 1992 tentang Kesehatan.

Salbiah. (2003). Konsep Diri http://duniapsikologi. dagdigdug.com /files/2008/12 /konsep-diri.pdf.

Diakses tanggal 3 maret 2017.

Sugiyono. 2010. Metode Penelitian Kuantitatif Kualitatif dan $R \& D, P T$, Jakarta: Rineka Cipta Wadyawati (2005). Pengaruh Dukungan Keluarga Terhadap Perubahan Respon Sosial-Emosional. Skripsi Program Studi Ilmu Keperawatan Fakultas Kedokteran Universitas Airlangga Surabaya. Yanuasti (2001). Dukungan Keluarga Naskah Publikasi: 25 mei 2008. rac.Uii.ac.id (server) document/public/20080525 ALL.rff.Semarang. Fakultas psikologis Universitas Katolik Soegi Japranata. Tanggal 15 maret 2017 